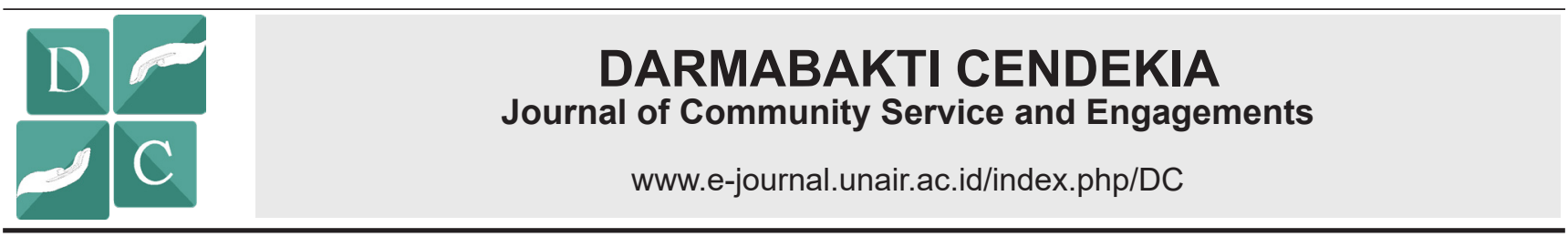

\title{
ANALYSIS OF THE INCIDENT RATE OF PEOPLE WITH A POTENTIAL RISK FOR HYPERTENTION AND DIABETES IN KENJERAN SUB-DISTRICT, SURABAYA
}

\section{ANALISIS KEJADIAN PASIEN BERESIKO HIPERTENSI DAN DIABETES PADA MASYARAKAT DI KECAMATAN KENJERAN KOTA SURABAYA}

Maya Septriana $^{1 *}$, Aliyah Siti Sundari ${ }^{1}$, Diyantoro ${ }^{1}$, Dwi Wahyu Indriati ${ }^{1}$, Anita Kurniati ${ }^{1}$, Ni Nyoman Purwani $^{1}$, Tofan Agung Eka Prasetya ${ }^{1}$, Fadilatus Sukma Ika Noviarni ${ }^{1}$, Shelly Wulandari ${ }^{1}$, Myrna Adianti ${ }^{1}$

${ }^{1}$ Department of Health, Faculty of Vocational Studies, Universitas Airlangga, Surabaya-Indonesia

\begin{abstract}
A B S T R A C T
Background: The number of people with diabetes mellitus in Indonesia is increasing every year. The data in 2016 showed that 1 of 11 adults could have diabetes mellitus. Uncontrolled and untreated diabetes mellitus can cause complications. Objectives: This activity aimed to determine the group of age that have a potential risk of hypertension and diabetes so that it could minimize the prevalence of disease and optimize human productivity. Methods: (1) Counseling about hypertension and diabetes, (2) Screening the people with a potential risk of hypertension using tensimeter and diabetes prediction using point-of-care testing (POCT) and urine dipstick. Results: The data were collected from 75 respondents with characteristics about $85,33 \%$ female and 14,67\% male. About 25 respondents $(33,33 \%)$ were suspected of hypertension. Based on age group, it showed that the highest incident rate of hypertension was found in the age group of 41-60 years $(41,86 \%)$, followed by the age group of $61-80$ years (20\%), $21-40$ years $(13,33 \%)$, and age under 20 years and above 80 years (0\%). The majority of respondents had a normal glucose level (90,67\%). Based on gender, there was 1 male respondent $(9,09 \%)$ and 5 female respondents $(7,81 \%)$ having glucose level higher than normal value (hyperglycemia). Conclusion: The age group with the highest potential risk for hypertension was 41-60 years, while for diabetes was 61-80 years. This activity provided information to prevent the potential risk leading to hypertension and diabetes.
\end{abstract}

\section{A B S T R A K}

Latar belakang: Jumlah penyandang diabetes melitus (DM) di Indonesia semakin meningkat setiap tahun. Data terbaru tahun 2016 menunjukkan bahwa 1 dari 11 dewasa dapat menyandang diabetes melitus. Diabetes melitus yang tidak terkendali dan tidak diobati dapat menyebabkan terjadinya komplikasi. Tujuan: Kegiatan ini bertujuan untuk menentukan kelompok usia yang memiliki risiko menderita hipertensi dan diabetes sehingga dapat meminimalkan angka prevalensi penyakit dan meningkatkan produktifitas warga. Metode: (1) penyuluhan penyakit diabetes dan hipertensi, (2) skrining penderita hipertensi dengan tensimeter dan diabetes dengan metode POCT dan Urine Striptest. Hasil: Dari 75 responden yang diperiksa, sebanyak 25 responden (33,33\%) menderita hipertensi Dari data yang diperoleh, responden lebih banyak pada kelompok jenis kelamin perempuan (85,33\%) daripada jenis kelamin laki-laki (14,67\%). Berdasarkan umur terlihat bahwa risiko responden menderita hipertensi paling tinggi pada kelompok umur 41-60 tahun (41,86\%), diikuti kelompok umur 61-80 tahun (20\%), 21-40 tahun (13,33\%), dan $0 \%$ pada kelompok umur $<20$ tahun dan $>80$ tahun. Secara keseluruhan mayoritas responden memiliki kadar gula darah normal (90,67\%). Berdasarkan jenis kelamin, terdapat 1 responden laki-laki dan 5 responden perempuan yang mengalami hiperglikemi. Kesimpulan: Kelompok umur 41-60 tahun paling berisiko terserang hipertensi sedangkan umur 61-80 paling berisiko terserang diabetes. Kegiatan ini memberikan informasi untuk mencegah resiko potensial penyakit diabetes dan hipertensi.

\section{A R T I C LE IN FO}

Recieved 22 February 2019

Accepted 8 May 2019

Online 28 June 2019

*Correspondence (Korespondensi): Maya Septriana

E-mail:

mayaseptriana@yahoo.co.id

Keywords:

Hypertention; Diabetes; Surabaya

\section{Kata kunci:}

Hipertensi; Diabetes; Surabaya 


\section{PENDAHULUAN}

Jumlah penyandang diabetes melitus (DM) di Indonesia semakin meningkat setiap tahun. Data terbaru tahun 2016 menunjukkan bahwa 1 dari 11 dewasa dapat menyandang diabetes melitus. Peluang tingginya angka diabetes melitus sangat erat kaitannya dengan gaya hidup dan pola makan yang tidak seimbang. Perubahan gaya hidup terutama di kota-kota besar, menyebabkan meningkatnya prevalensi penyakit degeneratif, seperti diabetes melitus (DM) (Waspadji, 2007).

Profil Kesehatan Indonesia 2012 menyatakan bahwa pada kelompok penderita diabetes usia 45-54 tahun menjadi penyebab kematian tertinggi kedua di daerah perkotaan yaitu sebesar $14,7 \%$ dan tertinggi di daerah pedesaan dengan persentase 5,8\% (Kemenkes, 2012). Tidak hanya pada usia lanjut saja, diabetes melitus bahkan menyerang anak, remaja, bahkan usia produktif yang dipengaruhi oleh gaya hidup dan pola makan. Diabetes melitus yang tidak terkendali dan tidak diobati dapat menyebabkan terjadinya komplikasi. Komplikasi utama yang dapat timbul antara lain serangan jantung, gagal ginjal, dan stroke. Komplikasi yang terjadi mengakibatkan terjadinya angka kematian dan angka kesakitan bukan hiperglikemi (Pernama, 2013).

Menurut data dari Dinas Kesehatan Provinsi Jawa Timur (2011) dalam Wulandari (2013), penyakit diabetes melitus termasuk dalam sepuluh penyakit terbanyak disamping ISPA, diare, demam berdarah, difteri, penyakit kulit, penyakit lambung, dan penyakit kardiovaskuler (jantung). Sekitar 69.018 orang dari 37 juta penduduk di Jawa Timur menderita diabetes melitus. Kota Surabaya menempati urutan pertama dari kota/kabupaten dengan jumlah penderita diabetes melitus terbanyak yakni 14.377 orang per tahun.

Selama periode Januari hingga Mei 2014, penyakit endokrin dan metabolik termasuk dalam 10 penyakit terbanyak berdasarkan data Profil Kota Surabaya, salah satunya yaitu diabetes melitus. Angka kejadian penyakit diabetes melitus di kota Surabaya menempati urutan tertinggi kedua setelah hipertensi. Berdasarkan catatan Dinas Kesehatan Kota Surabaya (2012) terdapat 212.262 kasus baru diabetes melitus tipe 2, kasus tahun sebelumnya yaitu sebanyak 116.518 kasus, dan korban meninggal karena penyakit tersebut berjumlah 73 orang (Putri, 2015). Upaya pengendalian terhadap penyakit diabetes telah banyak dilakukan, meliputi pendekatan faktor risiko penyakit melalui konseling dan deteksi dini (pemeriksaan gula darah, dislipidemia, dII), serta dengan meningkatkan kewaspadaan masyarakat akan faktor risiko penyakit melalui pos pembinaan terpadu yang dilakukan secara rutin dan periodik (Kemenkes, 2014).
Masyakarat Kenjeran hidup dalam lingkungan padat penduduk dengan tingkat perekonomian dengan latar belakang bervariasi seperti pagawai, nelayan, penjual makanan keliling, buruh pabrik dan ibu rumah tangga. Berdasarkan pengamatan yang dilakukan pada beberapa warga di dua kelurahan tersebut, pengetahuan masyarakat tentang gejala penyakit diabetes dan hipertensi serta bahayanya masih sangat rendah. Berdasarkan uraian di atas, kegiatan ini penting dilakukan untuk memberikan informasi dini kepada masyarakat khususnya masyarakat kenjeran tentang hipertensi dan diabetes melitus serta adanya upaya deteksi dini terhadap resiko penyakit diabetes dan hipertensi untuk meningkatkan kualitas hidup dan taraf hidup masyarakat. Sehingga upaya pengendalian terhadap penyakit diabetes bias dilakukan dengan pendekatan faktor risiko penyakit melalui konseling dan deteksi dini.

\section{METODE}

\section{Tempat}

Kegiatan Pengabdian Masyarakat (Pengmas) ini dilaksanakan tanggal Juli - Agustus 2018. Kegiatan ini diikuti oleh 75 peserta yang merupakan masyarakat atau pasien yang berkunjung untuk memeriksakan diri ke klinik St. Marinus Kenjeran, Surabaya.

\section{Penyuluhan}

Topik penyuluhan yang dilakukan meliputi penyakit diabetes (gejala, penyebab, pencegahan dan pengobatan yang tepat), yang akan disampaikan oleh tenaga medis, yang berkompeten dalam bidang Kesehatan.

\section{Skrining Penderita Diabetes}

Kegiatan ini merupakan kegiatan surveilans untuk skrining warga yang menderita penyakit diabetes. Jumlah target warga yang akan dilakukan skrining adalah sebanyak 75. Skrining dilakukan dengan cara pemeriksaan dengan alat POCT antara lain pemeriksaan Gula Darah dan pemeriksaan sampel Urin menggunakan Striptest.

\section{Observasi}

Observasi dilakukan terhadap proses pelaksanaan kegiatan (pra dan pasca kegiatan) berdasarkan perencanaan yang telah dibuat. Observasi dilaksanakan setelah setiap tindakan yaitu penyuluhan dan pemeriksaan dilakukan.

\section{Evaluasi}

Evaluasi yang dilakukan berupa hasil langsung (pendampingan terhadap masyarakat (mitra) dan 
tidak langsung (kuisioner). Hasil observasi akan dipergunakan sebagai dasar evaluasi kegiatan yang telah terlaksana (tepat sasaran). Kegiatan evaluasi dilakukan untuk mengetahui kendala, kelemahan dan kekurangan selama proses implementasi dan kegiatan di lapangan. Setelah program ini berjalan diharapkan masyarakat di Kecamatan Kenjeran dapat mengurangi risiko penyakit diabetes dan melakukan penanganan yang tepat terhadap gejala diabetes.

\section{HASIL DAN PEMBAHASAN}

Kegiatan Pengabdian Masyarakat ini diikuti oleh 75 peserta. Berdasarkan hasil kegiatan ini, pemeriksaan terhadap karakteristik dari responden terdapat pada Tabel 1.

Tabel 1. Karakteristik Responden

\begin{tabular}{lccc}
\hline Parameter & Kategori & Jumlah & Persentase (\%) \\
\hline \multirow{2}{*}{ Jenis Kelamin } & Laki-laki & 11 & 14,67 \\
& Perempuan & 64 & 85,33 \\
\hline & $<20$ & 1 & 1,33 \\
& $21-40$ & 15 & 20 \\
Umur (tahun) & $41-60$ & 43 & 57,33 \\
& $61-80$ & 14 & 18,67 \\
& $>80$ & 2 & 2,67 \\
\hline
\end{tabular}

Dari data yang diperoleh, responden lebih banyak pada kelompok jenis kelamin perempuan (85,33\%) daripada jenis kelamin laki-laki (14,67\%). Pada parameter umur, diperoleh jumlah responden terbanyak pada kelompok umur 41-60 tahun (57,33\%), diikuti kelompok umur $21-40$ tahun (20\%), $61-80$ tahun (18,67\%), $>80$ tahun (2,67\%), dan $<20$ tahun (1,33\%).
Tabel 2 menyajikan distribusi kejadian hipertensi berdasarkan jenis kelamin dan umur. Dari 75 responden yang diperiksa, sebanyak 25 responden (33,33\%) menderita hipertensi. Dimana 1 responden diantaranya berjenis kelamin laki-laki (4\%) dan 24 respon lainnya berjenis kelamin perempuan (96\%). Berdasarkan umur terlihat bahwa risiko responden menderita hipertensi paling tinggi pada kelompok umur 41-60 tahun (41,86\%), diikuti kelompok umur 61-80 tahun (20\%), 21-40 tahun (13,33\%), dan 0\% pada kelompok umur $<20$ tahun dan $>80$ tahun.

Persentase risiko hipertensi pada laki-laki yang rendah daripada perempuan pada pemeriksaan yang telah dilakukan tidak sesuai dengan yang telah dilaporkan oleh Susanto (2010) dan Hananta dan Diestesien (2011). Menurut Sutanto (2010) kaum lakilaki didaerah perkotaan lebih banyak mengalami kemungkinan menderita hipertensi dibanding kaum perempuan. Pada pria hipertensi berkaitan erat dengan pekerjaan seperti perasaan kurang nyaman terhadap pekerjaan dan pengangguran. Sementara itu menurut Hananta dan Diestesien (2011), jenis kelamin berpengaruh terhadap kadar hormon yang dimiliki seseorang. Esterogen yang dominan dimiliki wanita diketahui sebagai faktor protektif/ perlindungan pembuluh darah, sehingga penyakit jantung dan pembuluh darah (kardiovaskuler) lebih banyak ditemukan pada pria yang kadar esterogennya lebih rendah daripada wanita.

Parameter umur menunjukkan bahwa risiko hipertensi paling tinggi ditemukan pada kelompok umur 41-60 tahun. Semakin lanjut usia seorang, maka tekanan darah akan semakin tinggi karena beberapa faktor seperti elastisitas pembuluh darah yang berkurang, fungsi ginjal sebagai penyeimbang tekanan darah akan menurun (Hananta dan Diestesien (2011). Prevalensi hipertensi akan meningkat dengan bertambahnya umur (Muhammadun, 2010).

Tabel 2. Hasil Pemeriksaan Tekanan Darah

\begin{tabular}{|c|c|c|c|c|c|c|c|c|c|c|}
\hline \multirow{3}{*}{ Parameter } & \multirow{3}{*}{ Kategori } & \multicolumn{8}{|c|}{ Hasil Pemeriksaan } & \multirow{3}{*}{$\begin{array}{c}\begin{array}{c}\text { Resiko } \\
\text { Hipertensi } \\
(\%)\end{array} \\
\% \\
\end{array}$} \\
\hline & & \multicolumn{2}{|c|}{$\begin{array}{c}\text { Hipotensi } \\
\leq 90 / 60 \mathrm{mmHg}\end{array}$} & \multicolumn{2}{|c|}{$\begin{array}{c}\text { Normal } \\
>90 / 60- \\
120 / 80 \mathrm{mmHg}\end{array}$} & \multicolumn{2}{|c|}{$\begin{array}{c}\text { Pre-hipertensi } \\
>120 / 80- \\
140 / 90 \mathrm{mmHg}\end{array}$} & \multicolumn{2}{|c|}{$\begin{array}{c}\text { Hipertensi } \\
\geq 140 / 90 \\
\mathrm{mmHg}\end{array}$} & \\
\hline & & $\mathrm{n}$ & $\%$ & $\mathrm{n}$ & $\%$ & $\mathrm{n}$ & $\%$ & $n$ & $\%$ & \\
\hline \multirow{2}{*}{$\begin{array}{l}\text { Jenis } \\
\text { Kelamin }\end{array}$} & Laki-Laki & 0 & 0 & 5 & 19,23 & 5 & 20,83 & 1 & 4,00 & 9,09 \\
\hline & Perempuan & 0 & 0 & 21 & 80,77 & 19 & 79,17 & 24 & 96,00 & 37,5 \\
\hline \multirow{5}{*}{ Umur } & $<20$ & 0 & 0 & 1 & 3,85 & 0 & 0 & 0 & 0 & 0 \\
\hline & $21-40$ & 0 & 0 & 8 & 30,77 & 5 & 20,83 & 2 & 8,00 & 13,33 \\
\hline & $41-60$ & 0 & 0 & 14 & 53,85 & 11 & 45,83 & 18 & 72,00 & 41,86 \\
\hline & $61-80$ & 0 & 0 & 2 & 7,69 & 7 & 29,17 & 5 & 20,00 & 35,71 \\
\hline & $>80$ & 0 & 0 & 1 & 3,85 & 1 & 4,17 & 0 & 0 & 0 \\
\hline Jumlah (n) & & \multicolumn{2}{|c|}{0} & \multicolumn{2}{|c|}{26} & \multicolumn{2}{|c|}{24} & \multicolumn{2}{|c|}{25} & \\
\hline Persentase & & \multicolumn{2}{|c|}{$0 \%$} & \multicolumn{2}{|c|}{$34,67 \%$} & \multicolumn{2}{|c|}{$32 \%$} & \multicolumn{2}{|c|}{$33,33 \%$} & \\
\hline
\end{tabular}


Tabel 3. Hasil Pemeriksaan Gula Darah Sewaktu

\begin{tabular}{|c|c|c|c|c|c|c|c|c|}
\hline \multirow{3}{*}{ Parameter } & \multirow{3}{*}{ Kategori } & \multicolumn{6}{|c|}{ Hasil Pemeriksaan } & \multirow[b]{2}{*}{$\begin{array}{c}\text { Resiko Diabetes } \\
(\%)\end{array}$} \\
\hline & & \multicolumn{2}{|c|}{$\begin{array}{c}\text { Hipoglikemia } \\
<70 \mathrm{mg} / \mathrm{dL}\end{array}$} & \multicolumn{2}{|c|}{$\begin{array}{c}\text { Normal } \\
\geq 70-200 \mathrm{mg} / \mathrm{dL}\end{array}$} & \multicolumn{2}{|c|}{$\begin{array}{c}\text { Hiperglikemia } \\
\geq 200 \mathrm{mg} / \mathrm{dL}\end{array}$} & \\
\hline & & $\mathbf{n}$ & $\begin{array}{c}\text { Rerata (mg/ } \\
\mathrm{dL})\end{array}$ & $\mathbf{n}$ & $\begin{array}{c}\text { Rerata (mg/ } \\
\text { dL) }\end{array}$ & $\mathbf{n}$ & $\begin{array}{c}\text { Rerata (mg/ } \\
\mathrm{dL})\end{array}$ & $\%$ \\
\hline \multirow{2}{*}{$\begin{array}{l}\text { Jenis } \\
\text { Kelamin }\end{array}$} & Laki-Laki & 0 & 0 & 10 & 111,20 & 1 & 201,00 & 9,09 \\
\hline & Perempuan & 1 & 68,00 & 58 & 112,91 & 5 & 357,40 & 7,81 \\
\hline \multirow[t]{5}{*}{ Umur } & $<20$ & 0 & 0 & 1 & 90 & 0 & 0 & 0 \\
\hline & $21-40$ & 0 & 0 & 15 & 103,50 & 0 & 0 & 0 \\
\hline & $41-60$ & 0 & 0 & 39 & 115,9 & 4 & 279,00 & 9,52 \\
\hline & $61-80$ & 0 & 0 & 12 & 120,2 & 2 & 436,00 & 14,29 \\
\hline & $>80$ & 0 & 0 & 2 & 87 & 0 & 0 & 0 \\
\hline \multicolumn{2}{|c|}{ Jumlah dan rerata } & 1 & 68 & 69 & 112,66 & 6 & 331,33 & \\
\hline \multicolumn{2}{|c|}{ Persentase Kejadian } & \multicolumn{2}{|r|}{$1,33 \%$} & \multicolumn{2}{|r|}{$90,67 \%$} & & $8 \%$ & \\
\hline
\end{tabular}

Tabel 3 menunjukkan 6 dari 75 responden (8\%) memiliki kadar gula darah sewaktu lebih dari $200 \mathrm{mg} / \mathrm{dL}$ dengan nilai rerata $331,33 \mathrm{mg} / \mathrm{dL}$, dan secara keseluruhan mayoritas responden memiliki kadar gula darah normal (90,67\%). Berdasarkan jenis kelamin, terdapat 1 responden laki-laki dan 5 responden perempuan yang mengalami hiperglikemi dengan besar risiko yang tidak signifikan antara respon laki-laki dan perempuan. Resiko diabetes pada parameter umur menunjukkan bahwa kelompok umur yang berisiko paling tinggi ditemukan pada kelompok umur 61-80 tahun sebesar $14,29 \%$, diikuti oleh kelompok umur 41-60 tahun sebesar 9,52\%, sedangkan kelompok umur lainnya tidak ditemukan responden yang menderita hiperglikemia. Peningkatan kadar glukosa darah pada responden tersebut dapat disebabkan oleh beberapa faktor seperti peningkatan indeks massa tubuh (IMT), pertambahan umur, kebiasaan berolahraga, adanya riwayat DM dalam keluarga, dan kepatuhan meminum obat.

Berdasarkan hasil uji urin 6 respon yang memiliki nilai kadar gula darah pada pemeriksaan darah $>200 \mathrm{mg} / \mathrm{dL}$ menunjukkan bahwa 5 respon positif diabetes sedangkan 1 responden lainnya belum bisa dipastikan menderita diabetes (Tabel 4). Dari kelima responden yang positif diabetes, 2 responden memiliki kadar glukosa urin yang sangat tinggi ( $\geq 2000 /++++), 2$ responden memiliki kadar glukosa urin $500 \mathrm{mmol} / \mathrm{l}(++)$, dan 1 responden memiliki kadar glukosa urin $1000 \mathrm{mmol} / \mathrm{l}(+++)$. Selain pemeriksaan kadar glukosa urin, juga dilakukan pemeriksaan kadar protein urin untuk mengetahui apakah responden juga mengalami gangguan kesehatan lain selain diabetes. Hasil pemeriksaan protein urin menunjukkan 3 responden positif ditemukan protein dalam urinnya, 2 diantaranya memilki kadar protein yang sangat tinggi (300 $\mathrm{g} / \mathrm{l}$ atau +++$)$. Sementara pada pemeriksaan $\mathrm{pH}$ menunjukkan bahwa semua responden yang dilakukan pemeriksaan urin memiliki $\mathrm{pH}$ dibawah normal yakni 5,0.

Tabel 4. Hasil Pemeriksaan Urin Pada Pasien Beresiko Diabetes

\begin{tabular}{|c|c|c|c|c|c|c|}
\hline \multirow[b]{2}{*}{ No. } & \multirow{2}{*}{$\begin{array}{c}\text { Kadar } \\
\text { Gula } \\
\text { Darah } \\
\text { (mg/dL) }\end{array}$} & \multicolumn{5}{|c|}{ Hasil Pemeriksaan } \\
\hline & & $\begin{array}{l}\text { Pro- } \\
\text { tein } \\
(\mathrm{g} / \mathrm{l})\end{array}$ & $\begin{array}{l}\text { Interpre- } \\
\text { tasi }\end{array}$ & $\begin{array}{c}\text { Glukosa } \\
\text { ( mmol/ } \\
\text { l) }\end{array}$ & $\begin{array}{l}\text { Interpre- } \\
\text { tasi }\end{array}$ & $\mathbf{p H}$ \\
\hline 1 & 281 & 30 & + & $\geq 2000$ & ++++ & 5,0 \\
\hline 2 & 375 & 0 & - & $\geq 2000$ & ++++ & 5,0 \\
\hline 3 & 259 & 15 & \pm & 100 & \pm & 5,0 \\
\hline 4 & 505 & 300 & +++ & 1000 & +++ & 5,0 \\
\hline 5 & 367 & 15 & \pm & 500 & ++ & 5,0 \\
\hline 6 & 201 & 300 & +++ & 500 & ++ & 5,0 \\
\hline
\end{tabular}

\section{KESIMPULAN DAN SARAN}

Kelompok umur yang paling berisiko terserang hipertensi adalah umur 41-60 tahun sedangkan umur 61-80 paling berisiko terserang diabetes. Kegiatan ini memberikan informasi kepada masyarakat tentang risiko yang dapat memicu adanya penyakit diabetes dan hipertensi sehingga dapat melakukan pencegahan dini.

\section{UCAPAN TERIMA KASIH}

Terima kasih kepada klinik St. Marinus Kenjeran, Surabaya yang telah memberikan izin untuk melaksanakan kegiatan sehingga kegiatan dapat berjalan dengan lancar. Penulis menyatakan tidak ada konflik kepentingan dengan pihak-pihak yang terkait dalam kegiatan pengabdian kepada masyarakat ini. 


\section{DAFTAR PUSTAKA}

Hananta, I.P.Y., Diestesien, H.F. 2011. Deteksi Dini Dan Pencegahan 7 Penyakit Penyebab Mati Muda. Yogyakarta: Cetakan Pertama. Media Pressindo.

Kementrian Kesehatan RI. 2014. Bantuan Operasional Kesehatan. Jakarta: Kemenkes RI

Kementrian Kesehatan RI. 2012. Survei Demografi dan Kesehatan Indonesia. Jakarta: Kemenkes RI.

Muhammadun, A.S. 2010. Hidup Bersama Hipertensi: Seringai Darah Tinggi Sang Pembunuh Sekejap. Yogyakarta: Cetakan Pertama. In-Books.

Pernama, H. 2013. Komplikasi Kronik dan Penyakit Penyerta pada Diabetes. Bandung: Division of Endocrinology and Metabolism Department of Internal Medicine Padjadjaran University Medical School/Hasan Sadikin Hospital.

Putri, W. 2015. Hubungan Antara Perodititis dengan Diabetes Melitus Tipe 2 Ditinjau dari Aspek Destruksi Periodontal. Skripsi Sarjana. Medan: Fakultas Kedokteran Gigi Universitas Sumatra Utara.

Sutanto. 2010. Penyakit Modern: Hipertensi, Stroke, Jantung, Kolesterol, Dan Diabetes. Edisi Pertama. Yogyakarta: C.V Andi OFFSET.

Waspadji, S. 2007. Pedoman Diet Diabetes Melitus. Jakarta: FKUI.

Wulandari, O., Martin, S. 2013. Perbedaan Kejadian Komplikasi Penderita Diabetes Melitus Tipe 2 Menurut Gula Darah Acak. Jurnal Berkala Epidemiologi. Vol 1(2). Pp. 182-191. 